\title{
Uji altivitas antibakteri terhadap Escherichia coli dan antioksidan dari elkstrak air tumbuhan binara (Artemisia vulgaris L.)
}

\section{Activity antibacterial to Escherichia coli and antioxsidant of extract water of leaf binara plant (Artemisia vulgaris L.) after blanching}

\author{
Lia Febrina; Ida Duma Riris*; Saronom Silaban * \\ ${ }^{1}$ Jurusan Kimia, Fakultas Matematika dan Ilmu Pengetahuan Alam, Universitas Negeri Medan, Medan-Indonesia \\ *Korespondensi: dumariris@gmail.com; saronomsilaban@unimed.ac.id
}

\begin{abstract}
Binara (Artemisia vulgaris L.) merupakan salah satu jenis tumbuhan yang dimanfaatkan sebagai obat dan banyak terdapat di Kabanjahe, Kabupaten Karo, Sumatera Utara. Masyarakat Karo secara turun temurun menggunakan tanaman ini sebagai obat diare.Penelitian ini bertujuan untuk mengetahui daya hambat antibakteri dan aktivitas antioksidan dari ekstrak daun binara hasil blanching yang menggunakan pelarut air dalam proses ekstraksi secara refluks. Uji aktivitas antibakteri dilakukan terhadap bakteri Escherichia coli ATCC 25922 (gram negatif) menggunakan metode difusi. Ekstrak air daun binara yang diuji adalah konsentrasi $0 \% ; 2,5 \% ; 5 \%$. Aktivitas antibakteri diukur dari luas diameter zona bening disekitar sumur. Hasil penelitian menunjukkan ekstrak air daun binara memiliki aktivitas antibakteri berturut-turut pada konsentrasi $0 \% ; 2,5 \%$; dan $5 \%$ adalah $0 \mathrm{~mm} ; 18 \mathrm{~mm}$; dan $25,2 \mathrm{~mm}$. Sebagai kontrol positif digunakan kloramfenikol dan diperoleh daya hambat antibakterinya sebesar $28 \mathrm{~mm}$. Uji antioksidan dilakukan dengan metode peredaman DPPH (1,1-diphenyl-2picrylhydrazil). Hasil penelitian menunjukkan aktivitas antioksidan ekstrak air daun binara termasuk sedang (\% inhibisi 45,24\% dan IC 50114,23 ppm) dan sebagai kontrol positif digunakan vitamin C (\% inhibisi $56,27 \%$ dan IC 5072,75 ppm).
\end{abstract}

Kata kunci: antibakteri, antioksidan, Artemisia vulgaris L., Escherichia coli ATCC 25922, metode DPPH

\begin{abstract}
Binara (Artemisia vulgaris L.) is one of the types of plant sused as medicine in Kabanjahe, Karo, North Sumatera. Karo hereditary society use of this plant as a medicine for diarrhea. This research aims to know determine the ability of antibacterial and antioxidant activities from extracts of binara's leaves blanching results that use water in the solvent extraction process in reflux. Testing of antibacterial activity against the bacteria Escherichia coli ATCC 25922 (gram negative) using diffusion method. Water extracts of binara's leaves tested is the concentration $0 \% ; 2.5 \% ; 5 \%$. The antibacterial activity was measured from the diameter clear zone surrounding the well. The results showed antibacterial activity from water extract of binara's leaves successively at concentrations of $0 \% ; 2.5 \%$; and $5 \%$ is $0 \mathrm{~mm} ; 18 \mathrm{~mm}$; and $25.2 \mathrm{~mm}$. As positive controls used chloramphenicol and drag the ability of antibacterial obtainedby $28 \mathrm{~mm}$. Antioxidant test using the DPPH method (1.1-diphenyl-2-picrylhydrazil). The results showed antioxidant activity from water extracts of binara's leaves (\% inhibition $45.24 \%$ and $I C_{50} 114.23$ ppm) and as positive control used vitamin $C\left(\%\right.$ inhibition and $56.27 \%$ and $I C_{50} 72.75$ ppm).
\end{abstract}

Key words: antibacterial, antioxidant, Artemisia vulgaris L., Escherichia coli ATCC 25922, DPPH method

DOI: https://doi.org/10.24114/jpkim.v9i2.7621

Bakteri merupakan agen penyebab infeksi yang berarti menyebabkan terjadinya proses invasi dan pembiakan mikroorganisme di dalam jaringan tubuh (Darsana, 2012). Berdasarkan hal tersebut dapat diketahui bakteri sangat merugikan tubuh penderitanya apabila pembiakan mikroorganisme terjadi melebihi batas normal.
Salah satu agen penyebab infeksi bakterial adalah bakteri Escherichia coli (E. coli) Bakteri ini merupakan bakteri yang berada di dalam saluran pencernaan bagian bawah dan dapat berubah menjadi patogen jika perkembangannya di dalam tubuh melebihi batas normal. Bakteri ini dapat menyebar melalui kontaminasi debu atau melalui 
makanan dan minuman yang terkontaminasi feses (Darsana, 2012). Penyakit yang umumnya disebabkannya adalah penyakit diare. Metabolit sekunder dari ekstrak tumbuhan umumnya yang memiliki aktivitas sebagai antibakteri yaitu flavonoid dan saponin dan digunakan sebagai obat herbal (Thavaranjit, 2016). Flavonoid dapat berperan sebagai antibakteri dengan mengganggu fungsi dari mikroorganisme bakteri. Flavonoid menghambat pertumbuhan bakteri dengan menyebabkan terjadinya kerusakan permeabilitas dinding sel bakteri, mikrosom dan lisosom (Yunikawati, 2013). Sedangkan saponin memiliki mekanisme kerja yang mengakibatkan kerusakan membran sel sehingga keluarnya berbagai komponen penting dari dalam sel bakteri yaitu protein, asam nukleat dan nukleotida (Darsana, 2012). Selain itu juga terdapat tanin yaitu senyawa metabolit sekunder yang berfungsi sebagai antibakteri. Tanin merupakan komponen zat organik yang sangat kompleks terdiri dari senyawa fenolik yang sukar dipisah dan sukar mengkristal, mengendapkan protein dari larutannya dan bersenyawa dengan protein tersebut (Malangngi, 2012).

Senyawa seperti flavonoid dan tanin juga mampu menghambat reaksi oksidasi melalui mekanisme penangkapan radikal (radical scavenging) dengan cara menyumbangkan satu elektron pada elektron yang tidak berpasangan dalam radikal bebas, sehingga banyaknya radikal bebas menjadi berkurang (Pokorny et al., 2001). Sehingga selain berfungsi sebagai antibakteri, tumbuhan binara juga berfungsi sebagai antioksidan karena dapat menangkal radikal bebas. Radikal bebas adalah suatu molekul yang relatif tidak stabil dengan atom yang pada orbit terluarnya memiliki satu atau lebih elektron tidak berpasangan (Kumar, 2012). Radikal bebas pada konsentrasi yang tinggi dapat menghasilkan stress oksidatif yang menyebabkan kerusakan struktur sel, termasuk kerusakan lipid, protein dan DNA. Adanya radikal bebas dalam tubuh menjadi penyebab dari berbagai penyakit kronis dan degeneratif (Pham-Huy et al., 2008).

Antioksidan adalah substansi yang diperlukan tubuh menetralisir radikal bebas dan mencegah kerusakan yang ditimbulkan oleh radikal bebas, melengkapi kekurangan elektrolit yang dimiliki radikal bebas dan menghambat terjadinya reaksi berantai dari pembentukan radikal bebas yang dapat menimbulkan stress oksidatif (Prakash et al., 2001). Ketidakseimbangan antara radikal bebas dan antioksidan dapat menyebabkan keadaan stress oksidatif yang mengakibatkan kerusakan sel, jaringan hingga organ tubuh. Langkah tepat untuk mengurangi stres oksidatif adalah mengurangi paparan radikal bebas (Khaira, 2010). Tubuh tidak mempunyai sistem pertahanan antioksidan yang berlebih, sehingga jika terjadi paparan radikal berlebih maka dibutuhkan antioksidan eksogen (Sunarni dkk., 2007).

Salah satu tumbuhan yang dimanfaatkan sebagai obat diare oleh masyarakat Karo secara turun temurun adalah tumbuhan binara (Artemisia vulgaris L.). Tumbuhan binara (Artemisia vulgaris L.) merupakan tumbuhan liar yang tumbuh liar di ladang dan pinggir jalan disekitar daerah Kbanjahe, Karo, Sumatera Utara. Tumbuhan binara (Artemisia vulgaris L.) juga telah digunakan untuk mengatasi sakit haid, analgesik, keguguran, diuretika, nyeri ulu hati, disentri, muntah darah, batuk berdahak, keputihan, mimisan dan pendarahan usus karena mengandung senyawa bioaktif yang berkhasiat untuk mengatasi penyakit (Bangol, dkk., 2014). Berdasarkan laporan penelitian yang telah dilakukan, tumbuhan binara (Artemisia vulgaris L.) mengandung senyawa bioaktif berupa minyak atsiri, saponin dan flavonoid (Bunrathep et al., 2005).

Aktivitas antioksidan kobis meningkat $9 \%$ yang dibandingkan dengan tanpa blanching. Blanching gandum setelah pemanenan pada suhu $100{ }^{\circ} \mathrm{C}$ menunjukkan peningkatan fenol total tepung gandum. Demikian juga pengaruh blanching jagung dapat meningkatkan kadar fenol total (Pujimulyani dkk., 2010).

Aktivitas antioksidan pada kacang-kacangan, jagung, dan tomat yang diukur dengan metode 1,1-dihenyl-2-picrylhydrazil meningkat setelah dilakukan blanching (Kwan, 2007). Peningkatan aktivitas antioksidan tersebut diduga karena perlakuan blanching dapat menyebabkan komponen antioksidan mudah lepas dari matrik sel, sehingga meningkatkan hasil ekstraksi (Pujimulyani dkk., 2010).

\section{Metode}

\section{Bahan}

Bahan-bahan yang dipakai pada penelitian ini adalah tumbuhan binara (Artemisia vulgarisL.) yang diperoleh dari daerah Sumbul, Kabanjahe, Kabupaten Karo. Tumbuhan binara diperoleh dari ladang karena merupakan tumbuhan liar. Bahan yang digunakan dalam penelitian ini adalah kertas saring, kertas label, aluminium foil, asam askorbat yaitu vitamin $C$ yang berfungsi sebagai kontrol positif uji antioksidan, serbuk DPPH, metanol (p.a), $\mathrm{HCl}(100 \%, 1 \%, 2 \mathrm{~N}), \mathrm{H}_{2} \mathrm{SO}_{4} 2 \mathrm{~N}$, serbuk $\mathrm{Mg}$, kloroform, $\mathrm{NH}_{3} 10 \%, \mathrm{FeCl}_{3} 1 \%, \mathrm{KI}$, bismutsubnitrat, $\mathrm{HgCl}_{2}, \mathrm{I}_{2}$, etanol 70\%, aquades, NA (Nutrient Agar) dengan komposisi ekstrak daging sapi $0,5 \%(b / v)$; 
pepton $0,5 \%(\mathrm{~b} / \mathrm{v})$; agar $1,5 \%(\mathrm{~b} / \mathrm{v})$; isolat bakteri E. coli ATCC 25922, yang diperoleh dari Asean Farmasi Jakarta, kloramfenikol yang berfungsi sebagai kontrol positif uji antibakteri.

\section{Alat}

Alat-alat yang digunakan dalam penelitian ini adalah 1 set refluks, erlenmeyer $250 \mathrm{~mL}$, gelas ukur $10 \mathrm{~mL}$, beaker gelas $250 \mathrm{~mL}$, batang pengaduk, cawan porselen, kaca arloji, tabung reaksi, pipet ukur $5 \mathrm{~mL}$, pipet tetes, labu ukur $(10$ $\mathrm{mL}, 50 \mathrm{~mL}, 250 \mathrm{~mL}$ ), rak tabung, corong kaca, neraca analitik, hot plate, autoclave, spiritus, cawan petri, evaporator, mikropipet $10 \mu \mathrm{L}$, kuvet, spektroskopi UV-Vis (Thermo), dan inkubator (Thermo), dan jarum ose.

\section{Preparasi sampel}

Sebanyak $2 \mathrm{Kg}$ daun tumbuhan binara (Artemisia vulgaris L.) segar dipisahkan dari tangkainya kemudian dilakukan pencucian. Tumbuhan binara dilakukan blanching selama 1 menit dengan media larutan asam sitrat 0,05\% ditiriskan, dikeringkan dalam ruangan sambil dikipas sekali-sekali dan dibalik-balikkan. Proses pengeringan dilakukan di tempat yang teduh, terlindung dari sinar matahari selama proses pengeringan. Pengeringan dilakukan di tempat yang teduh dimaksudkan untuk menghindari rusaknya kandungan metabolit sampel akibat rusaknya kandungan metabolit sampel akibat adanya kontak langsung dengan sinar matahari. Dengan kondisi pengeringan yang demikian, diharapkan kandungan metabolit sekunder yang terdapat dalam sampel tidak akan rusak, setelah kering daun dipotong kecil-kecil untuk memperluas permukaan agar serbuk daun dapat secara maksimal dapat diekstrak.

Warna sampel semula adalah hijau segar, setelah kering hijau kehitaman. Berat sampel yang diperoleh setelah proses pengeringan $1 \mathrm{~kg}$ daun binara (Artemisia vulgaris L.) diperoleh sebanyak 356 gram $(35,60 \%)$ dengan pengurangan kadar air sekitar $64,40 \%$.

\section{Ekstraksi}

Daun binara yang telah halus dicampur dengan pelarut aquades. Ekstraksi dilakukan dengan cara refluks selama 3 jam, kemudian disaring dengan kertas saring. Filtrat yang diperoleh diuapkan dengan vakum rotatory evaporator sampai semua pelarut terpisah dari ekstrak.

Daun binara (Artemisia vulgaris L.) sebanyak 50 gram direfluks dan dievaporator sehingga diperoleh berat ekstrak daun binara dengan blanching sebanyak 3,3550 gram. Ekstrak yang diperoleh kemudian dilakukan uji fitokimia, uji antioksidan dan uji antibakteri.

Tabel 2

Hasil uji antioksidan dari ekstrak air daun binara (Artemisia vulgaris L.)

\begin{tabular}{cccccccc}
\hline $\begin{array}{c}\text { Ekstrak } \\
(\mathrm{ppm})\end{array}$ & Konsentrasi & \multicolumn{3}{c}{ Absorbansi } & $\begin{array}{c}\text { Rata-rata } \\
(\%)\end{array}$ & $\begin{array}{c}\% \text { Hambat } \\
\text { (ppm) }\end{array}$ & $\mathrm{IC}_{50}$ \\
\cline { 2 - 5 } & & $\mathrm{A} 1$ & $\mathrm{~A} 2$ & $\mathrm{~A} 3$ & 0,3438 & $25,62 \%$ & 114 \\
& 5 & 0,3410 & 0,3504 & 0,3400 & 0,3438 & 23 \\
\multirow{4}{*}{ Air } & 10 & 0,3373 & 0,3370 & 0,3404 & 0,3382 & $26,83 \%$ & 23 \\
& 25 & 0,3135 & 0,3217 & 0,3185 & 0,3179 & $31,22 \%$ & \\
& 50 & 0,2671 & 0,2705 & 0,2600 & 0,2659 & $42,47 \%$ & \\
& 100 & 0,2452 & 0,2575 & 0,2565 & 0,2531 & $45,24 \%$ & \\
\hline
\end{tabular}

Tabel 3

Hasil antioksidan dari kontrol positif (Vitamin C)

\begin{tabular}{ccccccc}
\hline $\begin{array}{c}\text { Sampel } \\
\text { (ppm) }\end{array}$ & Konsentrasi & \multicolumn{2}{c}{ Absorbansi } & $\begin{array}{c}\text { Rata-rata } \\
(\%)\end{array}$ & $\begin{array}{c}\% \text { Hambat } \\
(\mathrm{ppm})\end{array}$ & $\mathrm{IC}_{50}$ \\
\cline { 2 - 6 } & & $\mathrm{A} 1$ & $\mathrm{~A} 2$ & & & \\
\hline & 5 & 0,3216 & 0,3294 & 0,3255 & $29,58 \%$ & 72,75 \\
\multirow{2}{*}{ Vit C } & 10 & 0,3194 & 0,3119 & 0,3157 & $31,70 \%$ & \\
& 25 & 0,2803 & 0,2844 & 0,2824 & $38,90 \%$ & \\
& 50 & 0,2489 & 0,2527 & 0,2508 & $45,74 \%$ & \\
& 100 & 0,1989 & 0,2052 & 0,2021 & $56,27 \%$ & \\
\hline
\end{tabular}

Tabel 4

Diameter hambat ekstrak daun binara (Artemisa vulgaris L.) terhadap Eschericia coli

\begin{tabular}{ccc}
\hline Sampel & \multicolumn{2}{c}{ Antioksidan } \\
\cline { 2 - 3 } & Inhibisi (\%) & $\mathrm{IC}_{50}(\mathrm{ppm})$ \\
\hline Ekstrak air & 45,24 & 114,23 \\
Vit C & 56,27 & 72,75 \\
\hline
\end{tabular}


Tabel 5

Inhibisi dan $\mathrm{IC}_{50}$ dari ekstrak air daun binara (Artemisia vulgaris L.) dan Vitamin C

\begin{tabular}{cccccc}
\hline Ekstrak & Konsentrasi & \multicolumn{4}{c}{ Diameter daerah bening } \\
\cline { 3 - 6 }$(\mathrm{ppm})$ & $(\%)$ & $\mathrm{d} 1(\mathrm{~mm})$ & $\mathrm{d} 2(\mathrm{~mm})$ & $\mathrm{d} 3(\mathrm{~mm})$ & $\mathrm{d} 4(\mathrm{~mm})$ \\
\hline & 0 & 0 & 0 & 0 & 0 \\
Vit C & 2,5 & $18 \pm 0$ & $17 \pm 0,2$ & $18 \pm 0$ & $18 \pm 0$ \\
& 5 & $24 \pm 0,5$ & $25 \pm 0,2$ & $25 \pm 0,2$ & $25 \pm 0,2$ \\
& 0,02 & $28 \pm 0$ & $28 \pm 0$ & $28 \pm 0$ & $28 \pm 0$ \\
\hline
\end{tabular}

Uii antioksidan dan antibakteri

Uji antioksidan menggunakan DPPH mengacu pada metode Molyneux (2004) dengan sedikit modifikasi. Metode DPPH menggunakan 1,1difenil-2-pikrilhidrazil sebagai sumber radikal bebas. Reaksi ini menyebabkan terjadinya perubahan warna dari ungu ke kuning yang dapat diukur dengan spektrofotometer sinar tampak pada $\lambda 517 \mathrm{~nm}$.

Penelitan uji antibakteri menggunakan metode difusi mengacu pada metode Davis dan Stout (1971) dengan sedikit modifikasi. Metode difusi merupakan pengujian aktivitas antibakteri dengan menentukan kerentangan bakteri. Ekstrak sampel akan membentuk zona bening (daya hambat) sehingga diketahui bersifat sebagai antibakteri. Kontrol positif digunakan sebagai tolak acuan pada penentuan keaktivan ekstrak sebagai antibakteri.

\section{Hasil dan Pembahasan}

Randemen ekstrak air dari daun binara (Artemisia vulgaris $L$ ).

Untuk mendapatkan uji aktivitas yang maksimum lebih dahulu diblanching dengan menggunakan asam asetat 0,5\%. Randemen ekstrak air daun Binara (Artemisia vulgaris L) setelah dilakukan blanching adalah 6,71\%.

\section{Uji fitokimia}

Uji fitokimia dilakukan pada ekstrak daun binara dengan pelarut air. Uji dilakukan untuk mengidentifikasi alkaloid, flavonoid, saponin dan tanin dapat dilihat pada Tabel 1.

Tabel 1

Hasil uji fitokimia

\begin{tabular}{cc}
\hline Uji Fitokimia & Hasil \\
\hline Alkaloid & - \\
Flavonoid & + \\
Saponin & + \\
Tanin & + \\
\hline
\end{tabular}

Uii aktivitas antioksidan

Penentuan nilai aktivitas antioksidan pada penelitian ini menggunakan metode DPPH. Metode uji antioksidan dengan DPPH (2,2-difenil-1pikrilhidrazil) dipilih karena metode ini adalah metode sederhana, mudah, cepat dan hanya memerlukan sedikit sampel untuk evaluasi aktivitas antioksidan dari senyawa bahan alam sehingga digunakan secara luas untuk menguji kemampuan senyawa yang berperan sebagai pendonor elektron.Aktivitas diukur denganmenghitung jumlah pengurangan intensitas warna ungu DPPH yang sebanding dengan pengurangan konsentrasi larutan DPPH. Peredaman tersebut dihasilkan oleh bereaksinya molekul DPPH dengan atom hidrogen yang dilepaskan satu molekul komponen sampel yang menyebabkan terjadinya peluruhan warna DPPH dari ungu ke kuning, Hasil uji Antioksidan dari Ekstrak air daun Binara dapat dilihat pada Tabel 2.

Pada saat pengujian, warna dari larutan yang sudah diberikan DPPH yang semula berwarna ungu, kemudian perlahan berubah menjadi kuning, terutama pada konsentrasi yang besar. Hal ini menunjukkan terjadinya reaksi antara DPPH dan ekstrak daun binara yang dapat meredam radikal bebas (DPPH). Sebagai kontrol digunakan vitamin $C$, hasil antioksidan dari vitamin C dapat dilihat pada Tabel 3.

\section{Uii aktivitas antibakteri}

Uii Aktivitas antibakteri menggunakan metode sumur difusi. Sumur difusi adalah uji untuk menunjukkan daya hambat ekstrak daun binara (Artemisia vulgaris L.) terhadap bakteri E.Coli. Aktivitas antibakteri diukur dari diameter zona bening $(\mathrm{mm})$ pada media NA untuk ekstrak air yang dibandingkan dengan senyawa standar antibakteri kloramfenikol sebagai kontrol positif dan pelarut yangdigunakan dalam proses ekstraksi sebagai kontrol negatif.Ekstrak daun binara (Artemisia vulgaris L.) dibuat variasi konsentrasi yaitu 2,5\% dan 5\% untuk ekstrak air. Hasil diameter hambat ekstrak daun binara (Artemisia vulgaris L.) terhadap E.coli dapat dilihat pada Tabel 4.

\section{Uii aktivitas antioksidan}

Prinsip dari metode uji aktivitas antioksidan adalah pengukuran aktivitas antoksidan secara 
kuantitatif yaitu dengan melakukan pengukuran penangkapan radikal bebas DPPH oleh suatu senyawa yang mempunyai aktivitas antioksidan dengan menggunakan spektrofotometri UV-Vis sehingga dengan demikian akan diketahui nilai aktivitas peredaman radikal bebas yang dinyatakan dengan nilai $I_{50}$. Semakin kecil nilai $\mathrm{IC}_{50}$ maka aktivitas peredaman radikal bebas semakin tinggi. Prinsip kerja dari pengukuran ini adalah adanya radikal bebas stabil yaitu DPPH yang dicampurkan dengan senyawa antioksidan yang memiliki kemampuan mendonorkan hidrogen, sehingga radikal bebas dapat diredam (Wijaya, 2014). Inhibisi dan $I C_{50}$ dari Ekstrak air daun Binara (Artemisia vulgaris L) dapat dilihat padaTabel 5.

Nilai IC $_{50}$ (Inhibition Concentration 50) adalah konsentrasi antioksidan $(\mu \mathrm{g} / \mathrm{mL})$ yang mampu menghambat $50 \%$ radikal bebas. Nilai $I_{50}$ diperoleh dari perpotongan garis antara 50\% daya hambatan dengan sumbu konsentrasi, kemudian dimasukkan ke dalam persamaan $Y=a$ $+b X$ dimana $Y=50$ dan nilai $X$ menunjukkan $I_{50}$ (Molyneux, 2004).

Semakin kecil nilai $I_{50}$ berarti semakin tinggi aktivitas antioksidan, secara spesifik auatu senyawa dikatakan sebagai antioksidan sangat kuat jika nilai $\mathrm{IC}_{50}$ kurang dari 50ppm, kuat untuk $\mathrm{IC}_{50}$ bernilai 50-100ppm, sedang jika bernilai 100-150ppm, dan lemah jika nilai $I_{50}$ bernilai 151-200ppm (Molyneux, 2004).

Ekstrak air daun binara mempunyai aktivitas antioksidan yang sedang dengan (\% Inhibisi 45,24 dan $\left.I_{50} \quad 114,23 p p m\right)$ karena nilai $I_{50}$ berada dalam range 100-150 ppm. Antioksidan dapat membantu melindungi tubuh manusia melawan kerusakan yang disebabkan oleh senyawa oksigen reaktif (ROS, Reactive Oxygen Species) dan radikal bebas lainnya (Khaira, 2010). Grafik konsentrasi daun binara setelah blanching terhadap hambatan dapat dilihat pada Gbr 1.

Nilai IC50 $_{50}$ ekstrak daun binara dari hasil perhitungan persamaan regresi linear, dimana persamaan regresi linear dari ekstrak air yang didapat adalah $y=0,215 x+25,44$ dan $R^{2}=$ 0,847 . Koefisien y pada persamaan ini adalah sebagai $I C_{50}$, yaitu nilai $Y=50$, sedangkan nilai $X$ pada persamaan ini adalah konsentrasi dari ekstrak yang akan dicari nilainya, dimana nilai dari $X$ yang didapat merupakan besarnya konsentrasi yang diperlukan untuk dapat meredam $50 \%$ aktivitas radikal DPPH atau yang disebut juga dengan nilai $I_{50}$. Dari persamaan tersebut maka diperoleh nilai $\mathrm{IC}_{5}$ dari ekstrak air daun binara sebesar 114,23 ppm. Konsentrasi terhadap hambatan dari vitamin $C$ sebagai kntrol dapat dilihat pada Gbr 2.
Nilai $I_{50}$ vitamin $C$ didapat dari hasil persamaan regresi linear, dimana persamaan regresi linear dari vitamin $C$ yang didapat adalah $y=0,276 x+29,92$ dan $R^{2}=0,970$. Dari persamaan tersebut maka diperoleh nilai $\mathrm{IC}_{50}$ dari vitamin $C$ sebesar $72,75 \mathrm{ppm}$.

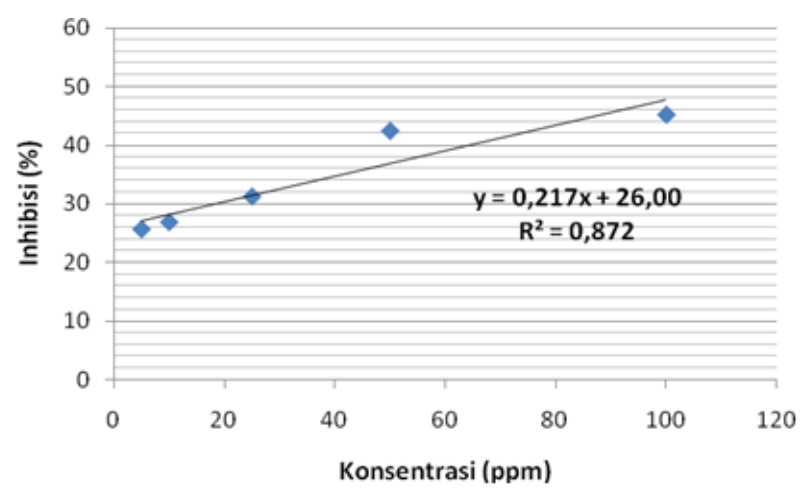

Gbr 1. Grafik konsentrasi terhadap hambatan dari ekstrak binara dengan blanching

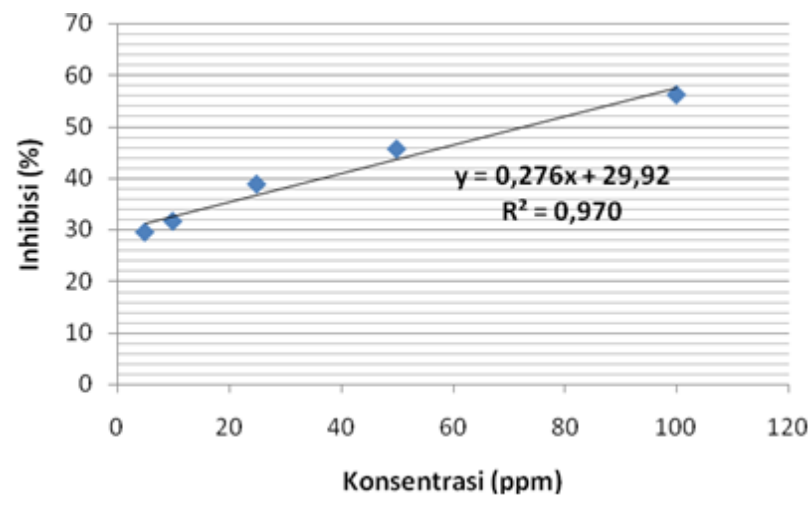

Gbr 2. Grafik Konsentrasi terhadap Hambatan dari Vitamin C

Uii aktivitas antibakteri

Metode dengan difusi sumur didasarkan dari kemampuan senyawa-senyawa antibakteri sampel untuk menghasilkan zona hambat (zona bening) disekeliling sumur uji terhadap bakteri yang digunakan sebagai penguji (Nurainy, 2008). Didalam satu cawan petri dibuat tiga sumur yang ditetesi ekstrak dengan konsentrasi yang sama. Dari ketiga daerah bening yang dihasilkan oleh lubang sumur yang diambil adalah diameter yang paling luas. Hal ini karena ketiga lubang sumur berada dalamsatu cawan petri dengan perlakuan yang sama. Pada tabel dapat dilihat bahwa ekstrak air daun binara pada konsentrasi $0 \%$ tidak menghasilkan zona bening karena yang digunakan adalah pelarutnya sebagai kontrol negatif, hal ini berarti bahwa pelarut air tidak memiliki aktivitas antibakteri. Zona bening ekstrak air daun binara 
$2,5 \%$ adalah $18 \mathrm{~mm}$, pada konsentrasi 5\% diameter zona beningnya 25,2 $\mathrm{mm}$. Zona bening yang dihasilkan ekstrak air semakin luas sebanding dengan semakin tingginya konsentrasi. Semakin tinggi konsentrasi maka zona bening yang dihasilkan juga semakin luas demikian juga sebaliknya semakin rendah konsentrasi maka luas zona bening yang dihasilkan juga semakin kecil.

Berdasarkan standar umum disebutkan bahwa diameter zona bening 10-20 mm memiliki daya hambat kuat, diameter zona bening 5-10 mm mempunyai daya hambat sedang dan diameter zona bening $<5 \mathrm{~mm}$ memiliki daya hambat lemah (Davis and Stout, 1971). Dari hasil yang diperoleh, diameter hambat oleh semua ekstrak tergolong kuat karena memiliki zona hambat 10-20 mm dan diatas $20 \mathrm{~mm}$. Sehingga berdasarkan hal tersebut ekstrak air daun binara konsentrasi $2,5 \%$ dan $5 \%$ sudah dapat dijadikan sebagai antibakteri.

Dari hasil penelitian daun binara (Artemisia vulgaris L.) yang memiliki aktifitas antimikroba yang paling baik adalah ekstrak air 5\% dengan daerah bening 25,2 mm.Diameter zona hambat yang dihasilkan semakin besar ketika konsentrasi ekstrak yang digunakan juga besar. Hal ini karena bakteri Escherichia coli merupakan bakteri gram negatif yang banyak mengandung lipid, sedikit peptigoglikan, membran luar berupa bilayer (berfungsi sebagai pertahanan selektif senyawasenyawa yang keluar atau masuk sel dan menyebabkan efek toksik). Membran luar terdiri dari fosfolipid (lapisan dalam), lipopolisakarida (lapisan luar) tersusun atas lipid A. Peptidoglikan pada E.coli bersifat polar sehingga antibakteri pada ekstrak air yang bersifat polar dapat masuk kedalam sel E.coli sehingga aktifitas antibakterinya kuat (Nuraini et al., 2008).

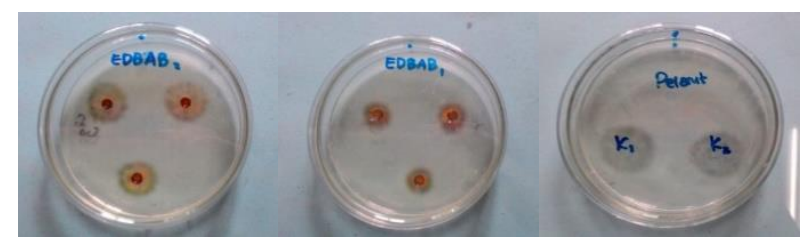

Gbr 3. Zona bening ekstrak daun binara (Artemisia vulgaris L.), pelarut dan kloramfenikol terhadap E.coli selama 24 Jam. $E D B A B_{1}$ : ekstrak air daun binara hasil blanching konsentrasi 2,5\%, EDBAB 2 : ekstrak air daun binara hasil blanching konsentrasi $5 \%, \mathrm{~K}$ : kloramfenikol

Pada penelitian aktifitas antibakteri dari ekstrak daun binara digunakan antibiotik standar yang biasa digunakan dalam pengobatan sebagai kontrol positif yaitu kloramfenikol. Respon yang diberikan oleh bakteri E.coli terhadap ekstrak dan kloramfenikol berbeda. Dimana bakteri E.coli yang digunakan aktifitasnya lebih efektif dihambat oleh kloramfenikol dengan diameter zona hambat yang dihasilkan adalah $28 \mathrm{~mm}$ dibandingkan dengan ekstrak daun binara (Artemisia vulgaris L.). Hal itu berarti bahwa kloramfenikol memiliki spectrum luas dengan kekuatan daya hambat yang tinggi dalam menghambat dan membunuh bakteri. Potensi daya hambat ekstrak daun binara dibandingkan dengan kontrol positif (kloramfenikol) dapat dilihat pada Tabel 6.

\section{Tabel 6}

Potensi ekstrak daun binara (Artemisia vulgaris L.) terhadap kloramfenikol

\begin{tabular}{lcc}
\hline $\begin{array}{l}\text { Ekstrak daun } \\
\text { bunara }\end{array}$ & $\begin{array}{c}\text { Konsentrasi } \\
(\%)\end{array}$ & $\begin{array}{c}\text { Potensi } \\
\text { terhadap kloramfenikol } \\
(\%)\end{array}$ \\
\hline Ekstrak air & 2,5 & 64,29 \\
& 5 & 90 \\
\hline
\end{tabular}

Potensi ekstrak daun binara semakin tinggi dengan semakin meningkatnya konsentrasi. Artinya semakin tinggi konsentrasi semakin banyak antibakteri yang berperan dalam penghambatan bakteri.

\section{Ucapan terima kasih}

Penulis mengucapkan terimakasih kepada dekan FMIPA yang memberi izin penelitian, dan reviewer yang telah menelaah tulisan ini.

\section{Kesimpulan}

Berdasarkan hasil penelitian dapat disimpulkan bahwa: (1) ekstrak air daun binara mengandung golongan senyawa flavonoid, saponin dan tannin; (2) hasil uji antioksidan menunjukkan bahwa ekstrak air daun binara memiliki tingkat antioksidan yang sedang karenanilai $\mathrm{IC}_{50}$ berada diantara 100-150 ppm; dan (3) hasil uji antibakteri menunjukkan bahwadaun binara dapat menghambat pertumbuhan bakteri Escherichia coli ATCC 25922 dan kecenderungan semakin tinggi konsentrasi ekstrak maka zona hambat yang terbentuk semakin besar.

\section{Daftar Pustaka}

Bangol., Erpi., Lidya, I.M. \& Jemmy, A. (2014). Aktivitas antioksidan ekstrak etanol dan nheksana dari daun rumput Santa Maria (Artemisia vulgaris L.) pada minyak ikan. Jurnal Ilmiah Sains Kimia Universitas Sam Ratulangi, $14(2)$. 
Bunrathep, S., Songsak, T. \& Ruangrungsi, N. (2005). Terpenoid contituents from leaves and cell cultures of Artemesia vulgaris var. indica and application of biotechnological techniques to increase davanone level. Journal Pharmaceutical Sciences, 1 2:147-153.

Darsana, I.G.O., Besung, I.N.K. \& Hapsari, M. (2012). Potensi daun binahong (Anredera cordifolia (Tenore) steenis) dalam menghambat pertumbuhan bakteri Escherichia coli secara in vitro. Jurnal Indonesia Medicus Veterinus, 1:337-351.

Davis, W.W. \& Stout, T.R. (1971). Disc plate method of microbiological antibiotic assay. Journal of Applied Microbiology, 22:659-665.

Khaira, K. (2010). Menangkal radikal bebas dengan antioksidan. Jurnal Saintek, 2:183187.

Kumar, U. \& Veeru, P. (2012). Assessment of antioxidant enzymes and free radical scavenging activity of selected medical plants. Journal Free Radicals And Antioxidants, 2:5863.

Kwan, A. (2007). Flavonoids and vascular disease. Diakses $19 \quad$ Januari 2016. <http://www.freevas.demon.co.uk/student/fla vonoids.html $>$.

Malangngi, L.P., Meiske S.S. \& Jessy J.E.P. (2012). Penentuan kandungan tanin dan uji aktivitas antioksidan ekstrak biji buah alpukat (Persea americana Mill.). Jurnal MIPA Unsrat, 1:5-10.

Molyneux, P. (2004). The use of the stable free radical diphenylpicrylhidrazil (DPPH) for estimating antioxidant activity. Journal Science Technology, 26:211-219.

Nurainy, F., Samsul, R. \& Yudiantoro. (2008). Pengaruh konsentrasi kitosan terhadap aktivitas antibakteri dengan metode difusi agar (sumur). Jurnal Teknologi Industri dan Hasil Pertanian, 13:117-125.
Pham-Huy., Lien, A., Hue, H. \& Pham-Huy, C. (2008). Free radical antioxidant in disease and health. Journal Biomed. Sciences, 4:89-96.

Pokorny, J., Yanishlieva, N., \& Gordon, M. (2001). Antioxidant in food; practical applications. CRC Press, New York.

Prakash, A., Rigelhof, F. \& Miller, E. (2001). Antioxidant Activity. Medalliaon Laboratories Analitycal Progress, $10(2)$.

Pujimulyani., D., Raharjo, S., Marsono, Y. \& Santoso, U. (2010). Aktivitas antioksidan dan kadar senyawa fenolik pada kunir putih (Curcuma mangga Val.) segar dan setelah blanching. Jurnal Agritech, 30(2).

Rohdiana D., Dede, Z.A. \& Arista, B. (2013). Aktivitas penghambatan pertumbuhan bakteri Escherichia coli oleh berbagai jenis teh dan seduhannya. Jurnal Penelitian Teh dan Kina, 16:37-44.

Sunarni, T., Pramono, S. \& Asmah, R. (2007). Flavonoid antioksidan penangkap radikal dari daun kepel (Stelechocarpus burahol (BI. Hook f. \& Th.). Majalah Farmasi Indonesia, 18:111116.

Thavaranjit, A.C. (2016). In vitro antibacerial activity and phytochemical screening of Strychnos potatorum seed extract. Der Pharma Chemica, 8:218-221.

Wijaya, D.P., Jessy E.P. \& Jemmy, A. (2014). Skrining fitokimia dan uji aktivitas antioksidan dari daun nasi (Phrynium capitatum) dengan metode DPPH (1,1-difenil-2-pikrilhidrazil). Jurnal MIPA UNSRAT, 3:11-15.

Yunikawati, M.P.A., Besung, I.N.K. \& Hapsari, M. (2013). Efektifitas perasan daun srikaya terhadap daya hambat pertumbuhan Escherichia coli. Jurnal Indonesia Medicus Veterinus, 2:170-179. 